\title{
Management of Sacral Giant Cell Tumor of Bone by Embolization: Case Report and Literature Review
}

S. Laatitioui ${ }^{1 *}$, H. Sami ${ }^{1}$, S. Barkiche ${ }^{1}$, A. Mharech ${ }^{1}$, N. Idrissi El Ganouni ${ }^{2}$, M. Darfaoui ${ }^{1}$, I. Lalya ${ }^{1}$, A. El Omrani ${ }^{1}$, M. Khouchani $^{1}$

${ }^{1}$ Department of Radiation-Oncology, Mohammed VI University Hospital, Marrakech, Morocco

${ }^{2}$ Department of Radiology, Mohammed VI University Hospital, Marrakech, Morocco

DOI: $10.36347 /$ simcr.2020.v08i05.022

| Received: 05.05.2020 | Accepted: 12.05.2020 | Published: 27.05.2020

*Corresponding author: Laatitioui Sana

\section{Abstract}

Giant cell tumors of bone are rare, characterized by their local aggressiveness and high risk of local recurrence. For tumors located in challenging anatomical such as sacrum, the surgical management is very difficult because of extensive bone destruction and the complexity of anatomical region. Advances in medical management of this disease have also demonstrated promise as an effective and alternative treatment. We reported a case of 14 years old boy, who is affected by sacral GCT revealed by lumbago-sciatica. The diagnosis was confirmed by surgical biopsy followed by anatomopathological examination. Arterial embolization was made because the tumor was unresectable and we noticed a good radio-clinical evolution. Embolization could be proposed as standard treatment for patients with incomplete excision or where surgery would induces functional deficits.

Keywords: Giant cell tumor, sacral vertebra, embolization.

Copyright @ 2020: This is an open-access article distributed under the terms of the Creative Commons Attribution license which permits unrestricted use, distribution, and reproduction in any medium for non-commercial use (NonCommercial, or CC-BY-NC) provided the original author and source are credited.

\section{INTRODUCTION}

Giant cell tumors are primary mostly benign bone tumor. Its represents a rare pathological entity (20\% of benign primary bone tumors and $5 \%$ of all primary bone tumors) [1]. It usually occurs in the metaepiphyseal region of long bones. The sacrum represents the 3rd most common site of TCG, its damage is estimated at 3 to $4 \%$ [2]. They are characterized by their local aggressiveness [3] and a significant risk of recurrence. Surgical treatment which is the mainstay of treatment for GCTs is very difficult for the tumor located in challenging anatomical such as sacrum, because of extensive bone destruction and the complexity of anatomical region. We report a case of a sacred giant cell tumor treated by embolization.

\section{CASE Report}

A 14-year-old male with no significant past medical history; presented with severe pain in the lumbosacral region for 4 months. The pain radiated from the lumbar spine into each thigh posterolaterally, until big toe without others symptoms such as sphincter disorders.

Physical examination showed spinal syndrome, with pain percussion of spinous processes.
Magnetic resonance imaging of the lumbar spine showed a sacral mass measure $88 * 53 * 25 \mathrm{~mm}$, it iinvolves the first sacral vertebra with extension to the vertebral canal and the posterior arch, and contains necrosis and calcified zones.

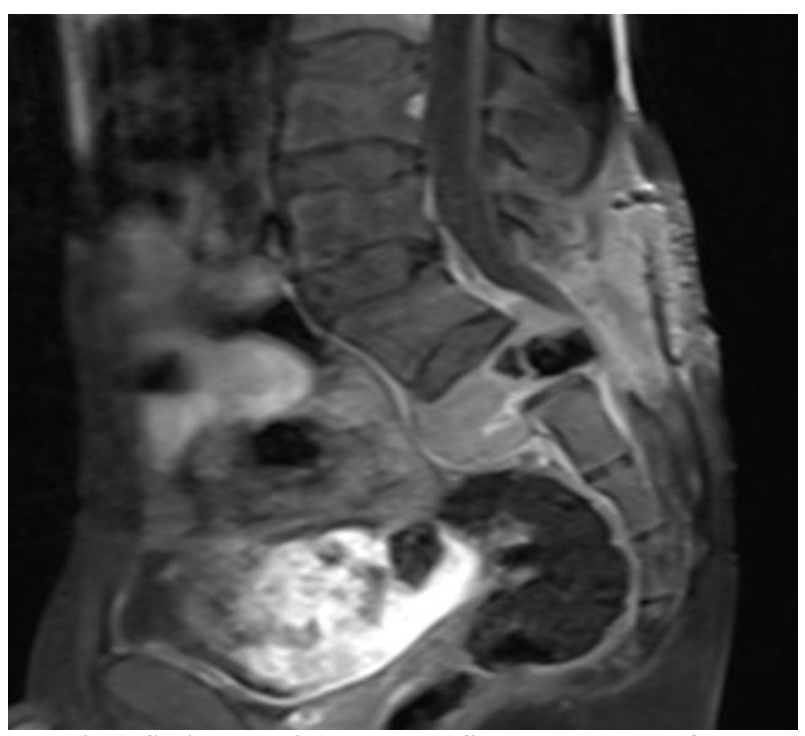

Fig-1: Sagittal MR image show a first sacral mass before embolization 
The diagnosis was confirmed by surgical biopsy followed by histological examination. It shows tumor proliferation containing two types of cells: multinucleated giant cells and monocytes.
Surgical treatment was impossible because of the tumor location. Treatment was discussed with the family, and the patient was scheduled for serial arterial embolization.

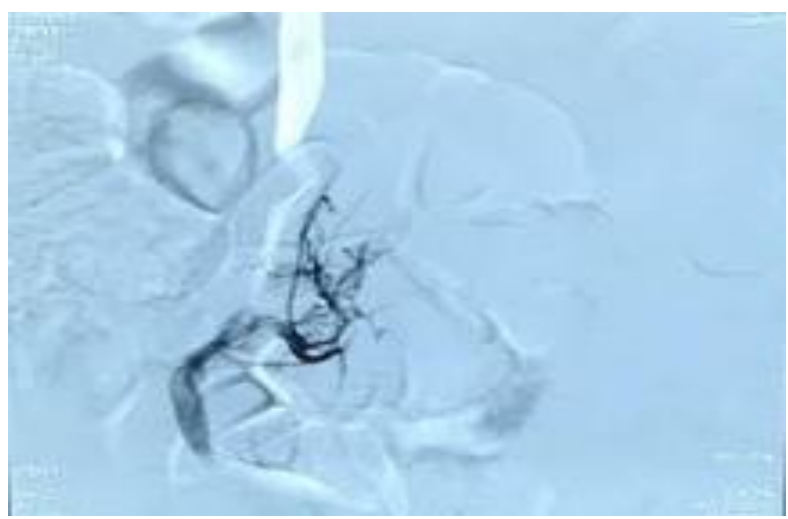

Fig-2: Succession of arterial embolization

Clinical evaluation was marked by pain relief after second embolization. MRI revealed tumor stability and regression of necrosis areas. The patient is scheduled for another embolization sessions

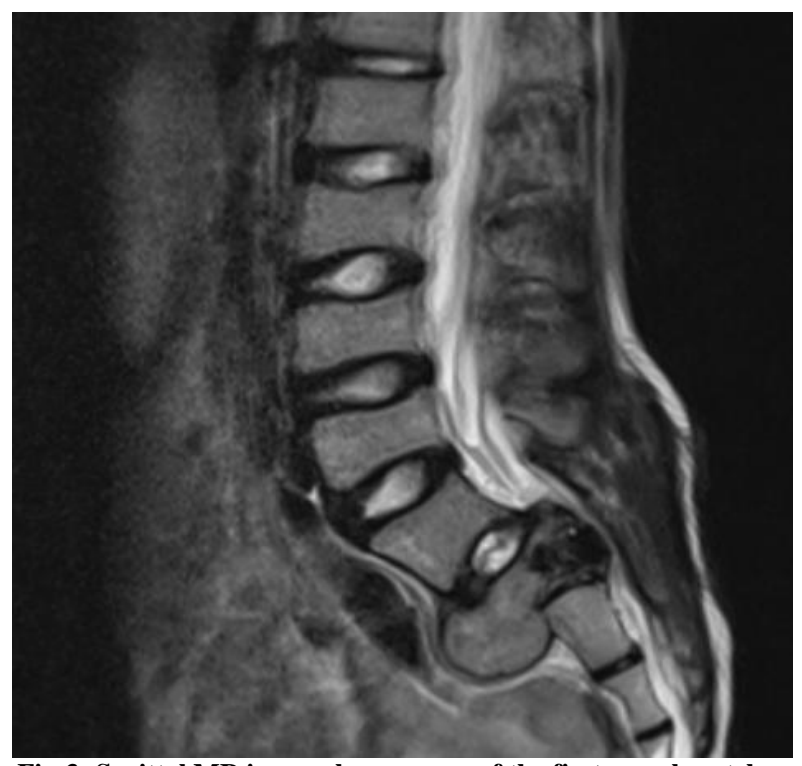

Fig-3: Sagittal MR image show a mass of the first sacral vertebra after second embolization

\section{DISCUSSION}

Giant cell bone tumors are relatively rare tumors, first described in 1818 by cooper and Travers [5]. It represents approximately $5 \%$ of all primary bone lesions in the USA and $20 \%$ in certain regions of Asia [6]. GCTB generally affect patients between 20 and 50 years of age with predominantly female [7]. They occur exceptionally before the age of 18 and after 50 [1].

The involvement of the extremities of the long bones is the most frequent with predilection of the epiphysometaphyseal region [8], mainly around the knee $(50 \%)$. Fifteen percent of GCTB are located in axial skeleton [9] which the pelvis and sacrum are more often involved accounting for 1.5 à $8.2 \%$ of bone GCT.

Paget's disease and the aneurysmal cyst are the most common diseases associated with giant cell tumor of the bone [10].

Clinically, pain is the most common symptom $(45.4 \%)$ [6], it is related to the extensive bone destruction and nerve compression. The bone pain begins slowly and increases with time. It can be triggered by pressure, associated with stiff spine, sometimes with inflammatory swelling or with neurological signs by radicular and / or medullary attack which can be confused with herniated disc [1]

Pelvic and sacral GCTs tend to be clinically silent in the early stages of development and cause few symptoms until they achieve a very large size and vascular [11].

The radiographic appearance of spinal GCTs is typically an osteolytic, expansile lesion with significant cortical destruction [3]. In the spine, GCTs typically involve the vertebral body, and can extend into the posterior elements and paraspinal tissues [3]. Computed tomography allows good assessment of cortical involvement and extension in soft tissue [12]. Magnetic resonance imaging (MRI) shows nonspecific image, with the tumor displaying decreased signal intensity on T1-weighted images, increased signal intensity on T2weighted images, and enhancement on gadoliniumenhanced images [13].

Histologically, GCTB contains three distinct cellular populations: multinucleated giant cells, recruited monocytes and bland stromal cells [6]. Areas of infarctoid necrosis are common, especially for large tumors. Historically, a GCTB classification system, based on the histological aspect of the tumor, was proposed by Jaffe and others in 1940 to stratify the 
tumor and predict its clinical behavior. Three grades of aggressiveness were described: ...... This classification system is no longer used due to its limited clinical value.

Although sacral GCTs are benign from the pathologic point of view, treatment is very difficult, optimal management is controversial, and there are no standard treatment guidelines [2].

The best surgical strategy for the treatment of sacral giant cell tumors continues to be refined over time [2]. Curettage combined with radiotherapy and marginal resection plus curettage can retain the sacral nerve root and maintain the completeness of the pelvic ring, but the rate of local recurrence is relatively high.

Extensive marginal resection and en bloc resection may maximally decrease the recurrence rate but increase the incidence of surgical complications [15, 16].

Brazilian team reported on their experience in radical surgery. They noticed a high risk of hemorrhage, infection and neurological deficit [7]. Patients would also suffer from sphincter disorders, pelvic and spinal instability responsible for the deterioration of their quality of life [7].

Arterial embolization is a therapeutic method, in which small materiel, are injected through catheter to clog tumor blood vessels. This procedure shrinks the tumor by depriving it of the oxygen- carry blood and other substance. It was proved to be curative treatment in sacral GCTs [11]. It is often used alone or in conjunction with other modalities: it can be proposed neoadjuvantly for GCTB to facilitate effective surgical curettage or resection.

The majority of GCTs treated by embolization obtained at least a favorable initial response, and around $50 \%$ of sustainable local control beyond 10 years of follow-up (17). Patients undergo a series of embolizations every 1-4 months until no new vessels are visualized feeding the tumor for an average of four sessions [17].

Lackman et al., [18] reported 5 cases of sacred TCG treated by embolization alone and 4 tumors remained stable over an average period of 6.7 years, although no decrease in tumor size was observed. Lin et al., [19] found that the response rate was $78 \%$ in a series of 18 sacred TCGs treated with a series of arterial embolization. The response to embolization was also sustainable, around $50 \%$ of patients, at 10 and 20 years of age.

The evaluation of the response to embolization is based on clinical and radiological criteria: Pain relief, decreased vascularity and peripheral ossification.
Another therapeutic option has been described in sacral GCTs is radiotherapy. It is reserved for inoperable and central tumors [20]. A dose of $45 \mathrm{~Gy}$ seems well tolerated and ensures good long-term local control [1]. The prognosis is marked by high risk of local recurrence which rate varies between 25 and $50 \%$ and malignant transformation which is in the range of 2 to $11 \%$ [1-6].

However, the frequency seems to be decreased with modern developments such as three-dimensional conformal RT, intensity-modulated RT and proton therapy enable delivery of elevated doses to the tumor with reduced dose to surrounding normal tissue [21]. These advantages may improve local control and decrease the risk of secondary malignancies [6].

Denosumab is a monoclonal antibody that specifically binds receptor of activator nuclear factor kappa-B ligand (RANKL), thereby down regulating osteoclast activity [3]. In June 2013, denosumab was approved by the FDA in the United States for unresectable GCTB treatments. A multicentric phase II study including 30 sites in 12 countries has shown he overall risk to benefit ratio for denosumab treatment in patients with GCTB remains favourable.

As for bisphosphonates, they are also used to stop osteolysis by inhibiting the activity of osteoclasts. In vitro studies demonstrate a tumoricidal effect on both the osteoclast and stromal cellular components of GCTB [23, 24].

Distant spread to the lungs is rare (2-3\%), but up to $10 \%$ of patients with recurrent GCTB can develop pulmonary metastases [25].

\section{CONCLUSION}

Giant cell bone tumors are benign, locally aggressive tumors with a high risk of local recurrence. The sacral location is complex anatomical region, it surgical excision is very difficult which can be responsible for functional deficit. Arterial embolization alone or as neo-adjuvant could be proposed as effective therapeutic alternative to reduce the extent of tumor as well as the morbidity of the surgery.

\section{REFERENCE}

1. Chekrine T, Tawfiq N, Bourhaleb Z, Benchakroun N, Jouhadi H, Sahraoui S, Benider A. Giant-cell bone tumors of the spine: Report of two cases and literature review [Deux cas de tumeurs osseuses à cellules géantes du rachis et revue de la littérature]. 2009.

2. Li G, Fu D, Chen K, Ma X, Sun M, Sun W, Li J, Cai Z. Surgical strategy for the management of sacral giant cell tumors: a 32-case series. The Spine Journal. 2012 Jun 1;12(6):484-91. 
S. Laatitioui et al, Sch J Med Case Rep, May., 2020; 8(5): 575-578

3. Luksanapruksa P, Buchowski JM, Singhatanadgige W, Rose PC, Bumpass DB. Management of spinal giant cell tumors. The Spine Journal. 2016 Feb 1;16(2):259-69.

4. Caudell JJ, Ballo MT, Zagars GK, Lewis VO, Weber KL, Lin PP, Marco RA, El-Naggar AK, Benjamin RS, Yasko AW. Radiotherapy in the management of giant cell tumor of bone. International Journal of Radiation Oncology* Biology* Physics. 2003 Sep 1;57(1):158-65.

5. Noël G, Jelloun HB, Feuvret L, Calugaru V, Mazeron $\mathrm{JJ}$, Habrand $\mathrm{JL}$. Les tumeurs à cellules géantes de la base du crâne: revue de la littérature à partir de deux cas. Cancer/Radiothérapie. 2006 Jun 1;10(4):175-84.

6. Ng VY, Davidson DJ, Kim EY, Pollack SM, Conrad III EU, Jones RL. The multidisciplinary management of giant cell tumor of bone. Expert review of anticancer therapy. 2014 Jul 1;14(7):783-90.

7. Viana ED, Batista KT, Carneiro Junior JL. Inoperable Sacral Giant Cell Tumor: Therapeutic Options and Pain Control. Revista brasileira de ortopedia. 2019 Jun;54(3):347-52.

8. Hunter CL, Pacione D, Hornyak M, Murali R. Giant-cell tumors of the cervical spine: case report. Neurosurgery. 2006 Nov 1;59(5):E1142-3.

9. Chakarun CJ, Forrester DM, Gottsegen CJ, Patel DB, White EA, Matcuk Jr GR. Giant cell tumor of bone: review, mimics, and new developments in treatment. Radiographics. 2013 Jan;33(1):197-211.

10. Erdogan B, Aydin MV, Sen O, Sener L, Bal N, Yalçin O. Giant cell tumour of the sixth cervical vertebrae with close relationship to the vertebral artery. Journal of clinical neuroscience. 2005 Jan 1;12(1):83-4.

11. Ji T, Yang Y, Wang Y, Sun K, Guo W. Combining of serial embolization and denosumab for large sacropelvic giant cell tumor: case report of 3 cases. Medicine. 2017 Aug;96(33).

12. Turcotte RE, Isler M, Doyon J. Tumeur à cellules géantes. In: Encyclopédie MédicoChirurgicale. Appareil locomoteur, 2001;14-772, 10.

13. Montgomery C, Couch C, Emory CL, Nicholas R. Giant cell tumor of bone: review of current literature, evaluation, and treatment options. The journal of knee surgery. 2019 Apr;32(04):331-6.

14. Noël G, Jelloun HB, Feuvret L, Calugaru V, Mazeron JJ, Habrand JL. Les tumeurs à cellules géantes de la base du crâne: revue de la littérature à partir de deux cas. Cancer/Radiothérapie. 2006 Jun 1;10(4):175-84.

15. Marcove RC, Sheth DS, Brien EW, Huvos AG, Healey JH. Conservative surgery for giant cell tumors of the sacrum. The role of cryosurgery as a supplement to curettage and partial excision. Cancer. 1994 Aug 15;74(4):1253-60.

16. Wallace S, Granmayeh M, Desantos LA, Murray JA, Romsdahl MM, Bracken RB, Jonsson K. Arterial occlusion of pelvic bone tumors. Cancer. 1979 Jan;43(1):322-8.

17. Lin PP, Guzel VB, Moura MF, Wallace S, Benjamin RS, Weber KL, Morello Jr FA, Gokaslan ZL, Yasko AW. Long- term follow- up of patients with giant cell tumor of the sacrum treated with selective arterial embolization. Cancer. 2002 Sep 15;95(6):1317-25.

18. Lackman RD, Khoury LD, Esmail A, DonthineniRao R. The treatment of sacral giant-cell tumours by serial arterial embolisation. The Journal of bone and joint surgery. British volume. 2002 Aug;84(6):873-7.

19. Lin PP, Guzel VB, Moura MF, Wallace S, Benjamin RS, Weber KL, Morello Jr FA, Gokaslan ZL, Yasko AW. Long- term follow- up of patients with giant cell tumor of the sacrum treated with selective arterial embolization. Cancer. 2002 Sep 15;95(6):1317-25.

20. Sanjay BK, Sim FH, Unni KK, McLeod RA, Klassen RA. Giant-cell tumours of the spine. The Journal of bone and joint surgery. British volume. 1993 Jan;75(1):148-54.

21. Roeder F, Timke C, Zwicker F, Thieke C, Bischof M, Debus J, Huber PE. Intensity modulated radiotherapy (IMRT) in benign giant cell tumors-a single institution case series and a short review of the literature. Radiation Oncology. 2010 Dec 1;5(1):18.

22. Chawla S, Blay JY, Rutkowski P, Le Cesne A, Reichardt P, Gelderblom H, Grimer RJ, Choy E, Skubitz K, Seeger L, Schuetze SM. Denosumab in patients with giant-cell tumour of bone: a multicentre, open-label, phase 2 study. The Lancet Oncology. 2019 Dec 1;20(12):1719-29.

23. Chang SS, Suratwala SJ, Jung KM, Doppelt JD, Zhang HZ, Blaine TA, Kim TW, Winchester RJ, Lee FY. Bisphosphonates may reduce recurrence in giant cell tumor by inducing apoptosis. Clinical Orthopaedics and Related Research®. 2004 Sep 1;426:103-9.

24. Cheng YY, Huang L, Lee KM, Xu JK, Zheng MH, Kumta SM. Bisphosphonates induce apoptosis of stromal tumor cells in giant cell tumor of bone. Calcified tissue international. 2004 Jul 1;75(1):717.

25. Balke M, Ahrens H, Streitbuerger A, Koehler G, Winkelmann W, Gosheger G, Hardes J. Treatment options for recurrent giant cell tumors of bone. Journal of cancer research and clinical oncology. 2009 Jan 1;135(1):149-5. 